\title{
Multinational Clients: A Source Of Competitive Advantage For Multinational Audit Firms
}

Anna M. Rose, (E-mail: rosea@Lincoln.ac.nz), Lincoln University, New Zealand

\begin{abstract}
This research evaluates the competitive advantages of the Big 6 audit firms in selected foreign markets, namely in Malaysia, Hong Kong, and the United Kingdom. In particular, the current study investigates audit pricing for multinational clients headquartered in the above regions. The analyses consider the degree of multinationality of the client and the locations of multinational clients' operations in order to gain insight into the determination of audit fees and audit firms' competitive advantages. The results indicate that audit fee premiums increase as the level of multinationality of the client increases in the Malaysian market, but not in the Hong Kong or UK markets. Also, in Malaysia, the magnitude of the Big 6 audit fee premium increases for clients with subsidiaries in developed countries. However, in Hong Kong and the United Kingdom, the location of client subsidiaries in developed countries does not provide additional competitive advantages for Big 6 firms.
\end{abstract}

\section{INTRODUCTION}

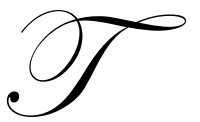

his research extends a recent study by Rose (1999) by evaluating the competitive advantages of the Big 6 audit firms ${ }^{1}$ in selected foreign markets, namely in Malaysia, Hong Kong, and the United Kingdom. The choice of geographic areas allows for a comparison of the multinational client market in regions with varying levels of economic development. ${ }^{2}$ In particular, the current study investigates audit pricing for multinational clients headquartered in the above regions. The analyses consider the degree of multinationality of the client and the locations of multinational clients' operations in order to gain insight into the determination of audit fees and audit firms' competitive advantages.

A conclusion of the Rose (1999) study states that the Big 6 accounting firms have a competitive advantage in the multinational client segment of the Malaysian market. The multinational clients appear to recognize, value, and pay for the higher quality provided by the Big 6 firms. But are all multinational clients the same? What characteristics of the multinational clients drive the above results? Does the "level" of multinationality of the client have an effect on the client's demand for audit services provided by different auditors? Theory suggests that higher Big 6 fee premiums will be assessed to "more" multinational clients, or clients with operations in various developed countries (as compared to ones with operations in developing countries). The investors associated with multinational clients having operations in developed countries should have a higher demand for audit services with international reputations. This research tests for Big 6 audit firm advantages in the multinational client segment.

It is important to examine these issues because the results provide additional information concerning the pricing strategies and demand for audit services in international markets. A demand for high audit quality in a

\footnotetext{
${ }^{1}$ Currently, only four of the largest public accounting firms remain (referred to as the Big 4). These include Deloitte \& Touche, KPMG, PricewaterhouseCoopers, and Ernst \& Young. This study was conducted before the merger of PriceWaterhouse and Coopers \& Lybrand, and before the demise of Arthur Andersen. These firms made up the Big 6 referred to in this study.

${ }^{2}$ According to the World Bank, "the use of the term 'country' does not imply political independence but may refer to any territory whose authorities present for it separate social and economic statistics" (World Bank 1995, p. viii). A similar application of this term is used in this study.
} 
developing market may be a signal of economic development in the region and the advancement of capital markets. The World Bank and the International Monetary Fund (IMF) provide assistance in developing regions to spur economic growth. It may be possible to promote growth by encouraging firms in developing countries to pursue multinational expansion and to establish subsidiaries in more developed regions. If firms face higher demand for quality audit services, then financial reporting will be improved and the costs of information to investors will decline. Such actions could assist developing countries in achieving much desired economic growth. The Big 6/4 audit firms may have an opportunity to provide additional assurance that financial information is of high quality.

The remainder of this paper is organized as follows. The next section presents a brief discussion of the three countries that are examined in the study. The following section includes theory development and introduces the research questions. The next section describes the research methodology used in this study and the results. The final section presents the conclusions and limitations of the study.

\section{BRIEF DISCUSSION OF REGIONS}

The choice of geographic regions examined in this study was driven to a large extent by the disclosure requirements for audit fees in the various locations. Being members and former members of the British Commonwealth, the three countries chosen for investigation have very similar accounting and auditing environments (Simon et al. 1992, Marston 1986, 34). A common requirement of all three countries is the disclosure of audit fees in the financial statements. Similar accounting and auditing environments in these regions allow for more meaningful comparisons of audit fee determinants than would be possible in countries with vastly different accounting histories.

One developing and two developed countries are included in the study. Malaysia is classified as a developing country, and Hong Kong and the United Kingdom are developed economies. The World Bank uses the level of gross national product (GNP) per capita as the criterion for classifying economies. The term "developing country" is used for countries that fall into the low and middle income categories. The World Bank (1996) classifies Malaysia as an upper middle income economy. Previous audit fee studies have found differing results for Malaysia compared to more developed nations. Simon et al. (1992) did not find a Big 6 audit fee premium, suggesting that firms and the securities market in Malaysia do not place a high value on audit quality. Other research (Rose 1999) finds that a Big 6 audit fee premium does exist in Malaysia, but only for the multinational client segment of the market.

Two developed countries are also examined: Hong Kong and the United Kingdom. Prior research has found a Big 6 fee premium in each of these countries. On July 1, 1997, Hong Kong ceased to be a British territory and became a Special Administrative Region of the People's Republic of China. Hong Kong will be responsible for its own administration (including its own laws) for the next 50 years. Changes are taking place rapidly in this region. For example, Hong Kong is replacing many of the British laws with Hong Kong ordinances (Ernst and Young 1990). The current study (using 1996 data) offers an opportunity to benchmark audit fee determinants in Hong Kong prior to its transition from British to Chinese rule.

The UK has a very long accounting and auditing tradition and is an example of a highly industrialized G-7 country. ${ }^{3}$ It is the only G-7 country for which audit fees are required disclosures (for the year of the study). The study by Rose (1999) calls for additional research of audit fees and multinationality for countries outside of the Asian region. The UK differs from Hong Kong in terms of political, cultural, and geographic aspects. The generalizability of the results to other developed countries is enhanced through the inclusion of both Hong Kong and the UK in the analyses made in this study.

\section{Theory and Hypotheses Development}

The issue of audit pricing, for both US and foreign audits, has received considerable attention in accounting literature. Simunic (1980) and other authors (e.g., Simon et al. 1992, Chung and Lindsay 1988, Palmrose 1986, Firth 1985, Simon 1985, Francis 1984) developed models for the determinants of audit fees in the US and foreign markets

\footnotetext{
${ }^{3}$ The G-7 group includes the following countries: UK, USA, Canada, France, Germany, Italy, and Japan.
} 
with considerable success. Special consideration has been devoted to examining the audit fees charged by the largest US audit firms, referred to in prior studies as the Big 8, Big 6, Big 6, and now Big 4 firms. Evidence suggests that the Big 4 firms charge fee premiums ${ }^{4}$ in the US market and in many foreign markets (see e.g., Rose 1999, Simon et al. 1992, Francis and Simon 1987, Palmrose 1986, Francis 1984).

A recent study by Rose (1999) examined the determinants of audit fees, the role of multinational enterprises in audit pricing, and large audit firm fee premiums in two foreign markets, Hong Kong and Malaysia. Successful foreign direct investment by the Big 6 firms stems from their ability to sustain a competitive advantage in these markets. Based on the theory of the multinational enterprise (MNE), the Rose study explained why the large accounting firms can charge fee premiums in certain foreign markets. However, the study documented that Malaysia did not offer the appropriate location conditions to allow the Big 6 firms to charge fee premiums to all clients. Developing countries, like Malaysia, pose certain location "disadvantages" that limit the ability of Big 6 firms to realize their competitive advantages to the full extent. The study further found that Big 6 firms were able to realize their competitive advantages in the multinational client segment of the Malaysian market. MNE clients must have unique characteristics that allow Big 6 firms to charge fee premiums. For example, MNE clients have many more international investors that would value the reputation and audit quality provided by the Big 6 firms. Also, through its subsidiaries, an MNE client operates in many different locations in the world and, therefore, is affected by the environments of many countries.

Indeed, Caves $(1996,94)$ writes "....MNEs might take part in different strategic groups than their national competitors" and "...MNEs domiciled in different source countries might compromise different strategic groups." Moreover, it has been documented in many studies that MNE firms are more profitable than their domestic competitors, after controlling for industry, firm size and financial structure (see e.g., Benvignati 1987, Shapiro 1980). For example, Shapiro (1980) investigated the profitability of MNE and domestic firms in Canada. US subsidiaries were found to be more profitable than the Canadian companies. The uniqueness of the MNE firms is especially evident when the MNEs first enter a foreign market. They bring with them proprietary assets, and they conduct business in unfamiliar ways. The domestic firms try to imitate the foreign entrant's competitive advantages. As the MNE ages, its market conduct becomes less differentiated form domestic competitors. This may provide one reason why Rose (1999) documented Big 6 fee premiums only for the multinational client segment in Malaysia and for both multinational and domestic clients in Hong Kong. MNE clients in Malaysia and Hong Kong are most likely at different stages of development, with Malaysian MNEs being "newer" to the market than Hong Kong MNE firms.

When Big 6 firms engage in foreign direct investment, they can benefit from internalization advantages (cost and demand synergies) by offering audit services to MNE clients that operate in many locations. Since a multinational client is mobile and has operations in several different countries, a multinational audit firm such as a Big 6 firm may actually reduce transaction costs for the client (Casson 1982). Rather than having to procure different auditors in all of the countries in which the MNE client operates, the client may experience cost savings by employing only one accounting firm that replicates its activities across regions. Big 6 firms are aware that they reduce total transaction costs for their multinational clients, and can increase their fees accordingly (as compared to domestic clients). MNE clients should also have a higher demand for Big 6 audits because their international investors should place a high value on the Big 6 reputations and superior audit quality. For the reasons described above, a higher fee premium is expected for multinational clients than for domestic clients in both developed and developing countries. This leads to the initial hypotheses.

Hypothesis 1) In Malaysia, a developing country, Big 6 audit firms will charge greater fee premiums to multinational clients than to domestic clients.

Hypothesis 2) In developed countries (Hong Kong and the United Kingdom), Big 6 audit firms will charge greater fee premiums to multinational clients than to domestic clients.

\footnotetext{
${ }^{4}$ Prior audit fee literature established a specific definition for the phrase "fee premium" (see e.g., Simon et al. 1992, Palmrose 1986, Simunic 1980). These studies have shown that the Big 6/4 auditors are able to charge higher fees than non-Big 6 auditors for audits of the same size, complexity, and risk (i.e., the Big 6 charge a "fee premium").
} 
It should be noted that MNE clients are not associated with more "audit failures" than domestic firms. ${ }^{5}$ A study by Hermanson et al. (1996) investigated the association of multinational risk factors with audit failures. The multinational risk factors examined in the study included foreign currency issues, international political risks, international economic risks, greater information asymmetry, and greater complexity. The authors did not find that the multinational risk factors contributed to failures. Rather, they noted that factors common to multinational and domestic enterprises - adverse economic conditions, litigation, and intra-company problems - were responsible for the failures of these companies. Therefore, the multinationality level of clients is not simply a surrogate for increased audit failure risk.

Further analysis of competitive advantages for Big 6 firms can be performed by distinguishing between the subsidiaries of the MNE clients. Not all MNE clients may provide the same level of competitive advantage for the Big 6 firms. Location advantages and disadvantages may play a role in the differential pricing of the Big 6 firms. Big 6 firms may charge different prices for its MNE clients, depending on the locations of the client's foreign operations. Haskins and Williams (1988) addressed a similar question. Their study investigated whether the Big 8 firms applied consistent pricing strategies across five countries (Australia, New Zealand, Ireland, the United Kingdom, and the United States). The findings supported similar pricing strategies for four of the five countries (Ireland was the exception). The authors did not attempt to explain why pricing strategies were different for Ireland, but they did cite a need for future research into audit fee pricing in countries with dissimilar accounting and auditing environments.

This study addresses the pricing strategies of Big 6 firms for MNE clients with subsidiaries in developing versus developed countries. For clients located in developing countries (Malaysia), MNEs with subsidiaries in developed countries should be charged higher audit fees by Big 6 firms than MNEs with subsidiaries in developing countries because higher audit quality should be demanded by these MNEs. It is likely that the investors in these MNE clients will come from developed countries where higher audit quality is demanded and the reputations of the Big 6 audit firms are more likely to be valued. Further, stricter reporting requirements for the subsidiaries in developed countries will increase the securities market's demand for quality, which will result in higher fees.

In addition, Big 6 firms may also charge higher fees for MNEs from developing countries with many developed country subsidiaries because of higher risk exposure. Big 6 auditors face higher risk exposure when the subsidiaries of MNE clients are located in developed countries. If an auditor experiences an audit failure for an MNE client with developed-country subsidiaries, that auditor may impair its reputation in the developed countries where the subsidiaries operate. Alternatively, if the MNE subsidiaries are located in developing countries, the chance of a loss to reputation due to audit failure will be lower because this information is less likely to reach other significant clients.

The risk factors introduced by the existence of subsidiaries in developed countries should not affect non-Big 6 auditors to the same extent as Big 6 auditors. The magnitude of possible loss due to damaged reputation would be higher for Big 6 auditors than for smaller local firms because Big 6 auditors are multinational enterprises with international reputations. A damaged reputation would be more difficult to reverse for these auditors.

In summary, the location disadvantages faced by Big 6 accounting firms operating in developing countries may be diminished to some extent when the client has subsidiaries in developed countries. The above discussion leads to the following hypothesis:

Hypothesis 3) In Malaysia, a developing country, a Big 6 audit firm fee premium will be of greater magnitude for MNE clients with subsidiaries in developed countries than for MNE clients with subsidiaries in developing countries.

Similar arguments can be made concerning the subsidiaries of MNE clients located in developed countries. A higher audit fee premium should be charged for MNEs with subsidiaries in developed countries than for MNEs with subsidiaries in developing countries. Again, fees may increase because of added reputation risk exposure (for the Big 6 audit firm) associated with many developed country subsidiaries. The arguments for increased disclosure

\footnotetext{
${ }^{5}$ An "audit failure" occurs when an unmodified audit opinion is issued shortly before a client declares bankruptcy.
} 
requirements and the demand for audit quality also apply to developed country MNEs, but to a somewhat lesser extent. MNEs in developed countries with subsidiaries in developing countries should be charged the same (or potentially lower) audit fees by the Big 6 firms than MNEs with subsidiaries in developed countries. An MNE located in a developed country already demands high audit quality. It is unlikely that the investors associated with the subsidiaries in developing countries would drive the demand for audit quality down. However, the scope of audits for MNEs with developing country subsidiaries should not be as large because developing countries have less rigorous disclosure requirements. Collectively, the above arguments lead to the following hypothesis:

Hypothesis 4) In developed countries (Hong Kong and the United Kingdom), a Big 6 audit firm fee premium will be of greater magnitude for MNE clients with subsidiaries in developed countries than for MNE clients with subsidiaries in developing countries.

\section{Research Methodology}

Several variations of the audit fee model have been developed in the literature (see e.g., Chung and Lindsay 1988, Francis and Simon 1987, Francis and Stokes 1986, Palmrose 1986, Firth 1985, Simon 1985, Simunic 1980). The base model used in this study includes variables that have been consistent determinants of audit fees in prior studies. The base model shown below tests for the existence of an overall audit fee premium in the three countries, Malaysia, Hong Kong, and the United Kingdom. For all testing, each country's data is analyzed independently to prevent confounding the results. Variables relevant to each hypothesis are added to the base model for testing, using ordinary least squares regression.

\section{Base Model}

LnAUDIT FEES $=b_{0}+b_{1}$ LnASSETS $+b_{2}$ SUBS $+b_{3}$ INVREC $+b_{4}$ LOSS $+b_{5}$ DEBT $+b_{6}$ OPINION $+b_{7}$ $\mathrm{MNE}+\mathrm{b}_{8}$ AUDITOR $+\mathrm{e}$

Table 1 provides a summary of the variables, their constructs, and a description of what each variable represents (for further discussion and justification of each variable, see prior audit fee studies, e.g., Rose 1999, Simon et al. 1992, Simunic 1980). The table also shows the predicted effect of each independent variable on the dependent variable, AUDIT FEES. The measures used to capture multinationality of the audit client deserve further description. Two different measures are used for this variable to confirm the robustness of the results. ${ }^{6}$

The degree of multinationality of the audit client can be captured in numerous ways. First, the MNE variable is calculated by dividing the number of foreign subsidiaries by the total number of subsidiaries of the client. This measure is a reasonable proxy for the extent of foreign operations. Previous studies have used such a variable to control for audit complexity (e.g., Chung and Lindsay 1988, Francis and Simon 1987, Simunic 1980). However, this variable measures more specific characteristics of the multinational client than simply complexity of operations. The variable can proxy for the degree of risk associated with international reputation loss for auditor firms and can also proxy for the demand by foreign investors for audit quality. Second, the degree of multinationality is measured by the ratio of foreign sales to total sales (see e.g., Rose 1999, Sundaram and Black 1992, Daniels and Bracker 1989, Geringer et al. 1989). This measure captures the magnitude of foreign sales, either through foreign direct investment or through export. While both measures are valid proxies for multinationality, each measure delivers a unique perspective on the degree of internationalization of the audit client. A positive relationship with audit fees is expected for the two different measures of the MNE variable.

\footnotetext{
${ }^{6}$ Each model is run two times (one time for each of the two MNE variables).
} 
TABLE 1

Variable Definitions

\begin{tabular}{|c|c|c|c|}
\hline Label & Construction & Description & $\begin{array}{c}\text { Predicted Effect } \\
\text { on Audit Fees as } \\
\text { Variable Increases }\end{array}$ \\
\hline \multicolumn{4}{|l|}{ Dependent Variable: } \\
\hline LnAUDIT FEES & Natural log of audit fees of the auditited client* & Audit fees for year of audit & \\
\hline Independent Variables: & & Variable controls for: & \\
\hline LnASSETS & Natural log of total assets of the auditited client* & Client size & + \\
\hline SUBS & $\begin{array}{l}\text { Total number of subsidiaries of the auditied client } \\
\text { that are at least } 50 \% \text { owned }\end{array}$ & Audit complexity & + \\
\hline INVREC & $\begin{array}{l}\text { Sum of audited client's inventories and receivables } \\
\text { divided by client's total assets }\end{array}$ & Audit complexity and risk & + \\
\hline LOSS & $\begin{array}{l}1 \text { if net income was negative for any of last } 3 \text { years, } \\
0 \text { otherwise }\end{array}$ & Audit risk & + \\
\hline DEBT & Debt-to-equity ratio & Audit risk & + \\
\hline OPINION & $\begin{array}{l}1 \text { if auditor issues a less than unqualifed opinion } \\
\text { for the client for year of study, } 0 \text { otherwise }\end{array}$ & Audit risk & + \\
\hline \multirow[t]{4}{*}{ MNE } & Two different measures used: & Degree of multinationality & \\
\hline & $\begin{array}{l}\text { 1. Number of foreign subsidiaries divided by } \\
\text { total number of subsidiaries of client }\end{array}$ & of audit client & + \\
\hline & 2. Foreign sales divided by total sales of client & & + \\
\hline & & Test variables & \\
\hline AUDITOR & 1 for Big 6 auditors, 0 otherwise & Audit firm type & + or none \\
\hline MNE*AUDITOR & MNE variable times AUDITOR dummy variable & Interaction of MNE and auditor & + \\
\hline DEVELOPSUB & $\begin{array}{l}\text { Number of developed countries with client subsidiaries } \\
\text { divided by total number of countries with client subsidiaries }\end{array}$ & $\begin{array}{l}\text { Level of involvment of client } \\
\text { in developed countries }\end{array}$ & + \\
\hline AUDITOR*DEVELOPSUB & AUDITOR dummy variable times DEVELOPSUB variable & $\begin{array}{l}\text { Interaction of auditor and } \\
\text { DEVELOPSUB }\end{array}$ & + \\
\hline
\end{tabular}

The AUDITOR variable in the base model is a dummy variable that distinguishes between Big 6 and non-Big 6 auditors. A positive and significant result for the AUDITOR variable would signify that Big 6 firms have a competitive advantage over non-Big 6 firms and are able to charge higher fees (i.e., fee premiums) than non-Big 6 auditors for audits of similar scope, complexity, and risk. Based on prior research, an overall Big 6 fee premium is expected in the developed countries, Hong Kong and the United Kingdom, and no overall premium is expected for the developing country, Malaysia.

The interaction between the AUDITOR variable and the MNE variable is added to the base model to test Hypotheses 1 and 2 (see Model 1). These hypotheses predict that Big 6 firms have a competitive advantage in the multinational client segment of the audit market in both developed and developing regions. A positive and significant coefficient on the interaction variable would indicate that Big 6 firms charge higher fee premiums for multinational clients than non-Big 6 firms. ${ }^{7}$

Model 1

LnAUDIT FEES $=b_{0}+b_{1}$ LnASSETS $+b_{2}$ SUBS $+b_{3}$ INVREC $+b_{4}$ LOSS $+b_{5}$ DEBT $+b_{6}$ OPINION $+b_{7}$ $\mathrm{MNE}+\mathrm{b}_{8}$ AUDITOR $+\mathrm{b}_{9}$ MNE*AUDITOR $+\mathrm{e}$

\footnotetext{
${ }^{7}$ In addition, an incremental $\mathrm{R}^{2}$ test is performed to test the contribution of the interaction term to the explanatory power of the model.
} 
Hypotheses 3 and 4 investigate the relationship between the location of the subsidiaries of MNEs and audit fees. Different MNE clients may provide different levels of competitive advantage for the Big 6 firms. For Hypotheses 3 and 4, samples containing only MNE clients will be examined. The question of interest is whether Big 6 auditors charge higher fee premiums for MNE clients with subsidiaries in developed countries than for clients with subsidiaries in developing countries. The following model is used to test the above hypotheses for each country individually.

Model 2 (for a reduced sample)

LnAUDIT FEES $=b_{0}+b_{1}$ LnASSETS $+b_{2}$ SUBS $+b_{3}$ INVREC $+b_{4}$ LOSS $+b_{5}$ DEBT $+b_{6}$ OPINION $+b_{7}$ $\mathrm{MNE}+\mathrm{b}_{8}$ AUDITOR $+\mathrm{b}_{9}$ DEVELOPSUB $+\mathrm{b}_{10}$ AUDITOR $*$ DEVELOPSUB $+\mathrm{e}$

FIGURE 1

Predicted result for DEVELOPSUB by AUDITOR Interaction

DEVELOPSUB by AUDITOR Interaction

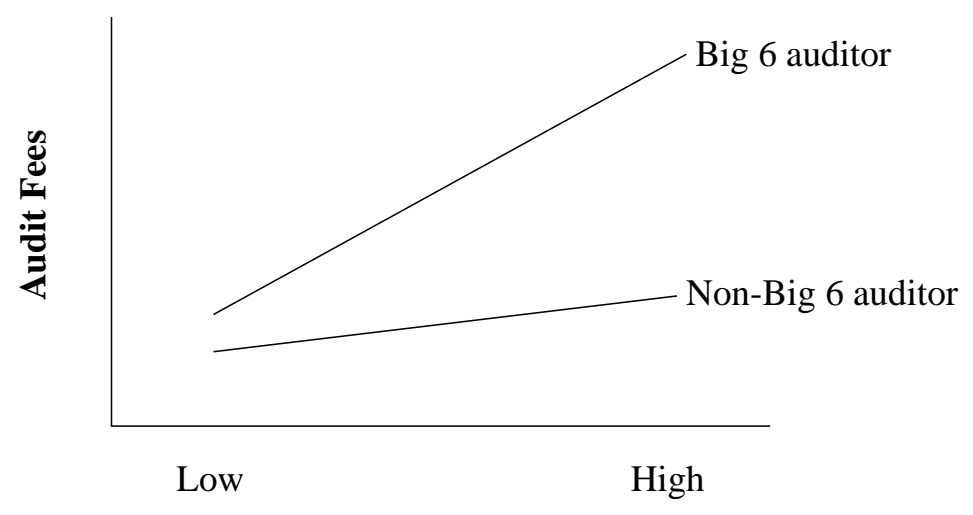

DEVELOPSUB

The variable DEVELOPSUB is calculated by dividing the number of developed countries that the client has subsidiaries in by the total number of countries of operation. The variable of interest for Hypotheses 3 and 4 is the interaction variable, AUDITOR by DEVELOPSUB, for which a positive significant coefficient is predicted. A positive coefficient for the interaction variable would imply that the Big 6 auditors require a greater increase in fees than non-Big 6 auditors for clients that have more subsidiaries in developed countries. This relationship is illustrated in Figure 1.

The following sources were used to collect the data for this study: Disclosure Select Worldscope database, Moody's Companies International database, and the 1997 Directory of Corporate Affiliations - International Public and Private Companies. Financial statement data, for the year 1996, was collected from Disclosure Select Worldscope. Audit fees are required financial statement disclosures for all regions included in the study. Subsidiary data, including location and number of subsidiaries, was collected from the Moody's database and the Directory of Corporate Affiliations. As in prior studies, companies in regulated industries, such as banks, financial institutions, and utility companies, were eliminated from initial samples (see e.g., Rose 1999, Francis and Stokes 1986). The resultant sample sizes are 224 companies for Malaysia, 280 companies for Hong Kong, and 917 companies for the United Kingdom. 


\section{RESULTS}

Table 2 presents the descriptive statistics for the sample data for each country. These statistics allow for some preliminary analysis and comparisons of the regions. The percentage of the sample firms audited by the Big 6 in each country is $71 \%$ for Malaysia, $84 \%$ for Hong Kong, and $83 \%$ for the UK. There is enough variation in auditor classification for the analyses of differences in auditor fees for Big 6 versus non-Big 6 auditors to be meaningful. It is also noteworthy to observe the number of multinational clients in each country. The table presents a count of firms in each sample that have at least one foreign subsidiary. The percentage of multinational firms to total firms in each sample is 50\% for Malaysia, $94 \%$ for Hong Kong, and 58\% for the UK.

Rose (1999) reported the percentage of multinational firms for Hong Kong (65\%) and Malaysia (24\%), but focused on foreign sales disclosures. The differences in the percentages are most likely due to the difference between these two measures of multinationality. Firms that have foreign sales are not necessarily involved in foreign direct investment. Also, firms with foreign subsidiaries may not have any foreign sales. Foreign subsidiaries may perform many functions other than sales, including purchasing, excavation of raw materials, production, finishing, or service. This study uses both measures of multinationality (number of foreign subsidiaries and foreign sales). Using more than one measure of multinationality provides some assurance that the results are consistent and robust.

The mean number of subsidiaries for the three samples is 22.86 for Malaysia, 29.13 for Hong Kong, and 13.82 for the UK. Malaysian companies are almost as large as those in Hong Kong. This is quite different from the results presented by Simon et al. (1992). Using a sample for the years 1987-1988, Simon et al. reported 24.2 as the mean number of subsidiaries for Hong Kong and 12.6 as the mean number of subsidiaries for Malaysia. The current sample suggests that the Malaysian market has grown considerably over the last decade.

\section{Malaysia}

The results for the Base Model and Model 1 for Malaysia are shown in Table 3. Table 3 includes two sets of results, one set for the foreign subsidiaries measure of multinationality (Test 1 ) and the other set for the foreign sales measure of multinationality (Test 2). Panel A of Table 3 presents the regression results for the Base Model: the model designed to test for an overall Big 6 audit fee premium in Malaysia. ${ }^{8}$ When using the foreign subsidiaries to total subsidiaries measure (Test 1$)$, the model is significant $(\mathrm{p}<.0001)$ with an $\mathrm{R}^{2}$ of $71.3 \%$. The control variables for total assets, total subsidiaries, and level of multinationality are positive and statistically significant at the .01 level. ${ }^{9}$ The percentage of assets in inventories and receivables is also positive and significant at the .025 level. The AUDITOR variable is significant at the .05 level, suggesting that Big 6 firms charge fee premiums across all clients in Malaysia. The environment in Malaysia has apparently changed substantially since prior studies were conducted. This is not surprising, as Malaysia is considered one of the fastest growing capital markets, and is currently placed in the uppermiddle income classification by the World Bank. However, the Base Model was also run on only non-multinational clients, and no evidence was found to support the existence of a Big 6 fee premium for the non-multinational market segment. ${ }^{10}$ In Malaysia, multinationality of the audit client plays a critical role in audit pricing by the Big 6 firms.

Hypothesis 1 predicts that, in developing countries like Malaysia, Big 6 auditor fee premium will increase with the level of multinationality of the client. Panel B of Table 3 reports the regression results for a model that includes the interaction of multinationality with auditor type (Model 1). The $\mathrm{R}^{2}$ for the model with the first MNE variable (foreign subsidiaries to total subsidiaries, Test 1 ) is equal to $71.9 \%$. The incremental $\mathrm{R}^{2}$ procedure is used in order to test for the significance of the interaction term. The t-statistic for the coefficient on the interaction term may not be a reliable test for significance because the $t$-statistic can be influenced by model specification. The incremental $\mathrm{R}^{2}$ procedure uses an F-statistic that is not corrupted by model specification.

\footnotetext{
${ }^{8}$ All regression models used in this study were tested for satisfaction of the regression assumptions. Normal probability plots indicate that no models violated the assumption of normality. Further, multicollinearity was not a significant problem. No variance inflation factor in any of the models exceeded 2.50 .

${ }^{9}$ The one-tail test is used for all analyses.

${ }^{10}$ Results not reported.
} 
TABLE 2

Descriptive Statistics

\begin{tabular}{|c|c|c|c|c|c|}
\hline $\begin{array}{c}\text { Malaysia } \text { (currency }=\text { Ringgit }) \\
\text { Variable }\end{array}$ & $\mathrm{N}$ & Mean & Deviation & Minimum & Maximum \\
\hline FEE & 224 & 227 & 277 & 14.00 & $2,163.00$ \\
\hline ASSETS & 224 & $1,406,764$ & $2,912,180$ & $34,335.00$ & $32,000,000.00$ \\
\hline SUBS & 224 & 21.86 & 30.22 & 1.00 & 301.00 \\
\hline INVREC & 224 & 0.35 & 0.20 & 0.00 & 0.89 \\
\hline DEBT & 224 & 0.76 & 0.81 & 0.001 & 4.84 \\
\hline Number of firms audited by Big 6 & 159 & & & & \\
\hline Number of multinational firms & 113 & & & & \\
\hline
\end{tabular}

\begin{tabular}{lrrrrr}
\multicolumn{2}{l}{ Hong Kong (currency $=$ Hong Kong dollar) } & & & & \\
\multicolumn{1}{r}{ Variable } & N & Mean & Deviation & Minimum & Maximum \\
\hline FEE & 280 & 2,918 & 6,397 & 120.00 & $88,893.00$ \\
ASSETS & 280 & $13,000,000$ & $34,278,116$ & $45,888.00$ & $390,000,000.00$ \\
SUBS & 280 & 29.13 & 26.48 & 0.00 & 260.00 \\
INVREC & 280 & 0.28 & 0.21 & 0.00 & 0.84 \\
DEBT & 280 & 0.70 & 2.15 & 0.00 & 25.93 \\
& & & & & \\
Number of firms audited by Big 6 & 234 & & & & \\
Number of multinational firms & 264 & & & & \\
\hline
\end{tabular}

\begin{tabular}{|c|c|c|c|c|c|}
\hline \multicolumn{6}{|c|}{ United Kingdom (currency = UK dollar) } \\
\hline Variable & $\mathrm{N}$ & Mean & Deviation & Minimum & Maximum \\
\hline FEE & 917 & 577 & 1,486 & 7.00 & $20,000.00$ \\
\hline ASSETS & 917 & 535,590 & $2,072,714$ & 713.00 & $33,000,000.00$ \\
\hline SUBS & 917 & 13.82 & 16.73 & 0.00 & 174.00 \\
\hline INVREC & 917 & 0.43 & 0.23 & 0.00 & 1.00 \\
\hline DEBT & 917 & 1.01 & 4.84 & 0.0001 & 93.50 \\
\hline Number of firms audited by Big 6 & 758 & & & & \\
\hline Number of multinational firms & 530 & & & & \\
\hline
\end{tabular}

Comparison of the $\mathrm{R}^{2}$ for the full model (Panel B, Test 1 of Table 3 ) and reduced model (Panel A, Test 1 of Table 3) yields an F value of 4.59. ${ }^{11}$ The MNE*AUDITOR interaction term is statistically significant $(\mathrm{p}<.05)$ and in the predicted positive direction. The result provides support for Hypothesis 1. Big 6 firms are able to charge higher fee premiums than domestic firms for MNE clients. The multinational segment of the audit market in Malaysia provides a source of competitive advantage for the Big 6 firms. The combination of their resources/skills and location-specific advantages allows Big 6 firms to charge above market prices for this market segment. The result is consistent with the dual markets hypothesis introduced in Rose (1999).

\footnotetext{
${ }^{11}$ The Base Model is the "reduced model" because it does not include the interaction term. Model 1 is the "full model" because the interaction term is included.
} 


\section{TABLE 3}

Malaysia - Base Model and Model 1

\begin{tabular}{|c|c|c|c|c|c|}
\hline $\begin{array}{l}\text { PANEL A } \\
\text { Base Model } \\
\mathbf{n = 2 2 4} \\
\end{array}$ & duced model & $\begin{array}{l}\text { Test } 1 \\
\text { MNE Variable = } \\
\text { Foreign Subs./Total Subs. }\end{array}$ & & $\begin{array}{l}\text { Test } 2 \\
\text { MNE Variable = } \\
\text { Foreign Sales/Total Sales }\end{array}$ & \\
\hline $\begin{array}{l}\text { Dependent } \\
\text { Variable } \\
\end{array}$ & $\begin{array}{l}\text { Independent } \\
\text { Variables }\end{array}$ & $\begin{array}{l}\text { Regression } \\
\text { Coefficient }\end{array}$ & t-statistic & $\begin{array}{l}\text { Regression } \\
\text { Coefficient }\end{array}$ & t-statistic \\
\hline LnFEE & $\begin{array}{l}\text { INTERCEPT } \\
\text { LnASSETS } \\
\text { SUBS } \\
\text { INVREC } \\
\text { LOSS } \\
\text { DEBT } \\
\text { OPINION } \\
\text { MNE } \\
\text { AUDITOR }\end{array}$ & $\begin{array}{r}-0.691 \\
0.375 \\
0.011 \\
0.422 \\
-0.223 \\
0.00007 \\
0.311 \\
1.371 \\
0.154 \\
\text { R-square }=.713 \\
\end{array}$ & $\begin{array}{r}-1.364 \\
9.990 * * * \\
7.312 * * * \\
2.119 * * \\
-1.206 \\
-0.150 \\
0.807 \\
6.029 * * * \\
1.943 *\end{array}$ & $\begin{array}{r}-1.225 \\
0.420 \\
0.012 \\
0.476 \\
-0.146 \\
-0.0004 \\
0.268 \\
0.014 \\
0.180 \\
\text { R-square }=.693 \\
\end{array}$ & $\begin{array}{r}-2.357 * * * \\
10.946 * * * \\
8.172 * * * \\
2.316 * * \\
-0.768 \\
-0.731 \\
0.674 \\
4.511 * * * \\
2.211 * *\end{array}$ \\
\hline $\begin{array}{l}\text { PANEL B } \\
\text { Model } 1 \text { - fu } \\
\text { n=224 } \\
\end{array}$ & lodel & $\begin{array}{l}\text { Test } 1 \\
\text { MNE Variable = } \\
\text { Foreign Subs./Total Subs. }\end{array}$ & & $\begin{array}{l}\text { Test } 2 \\
\text { MNE Variable = } \\
\text { Foreign Sales/Total Sales }\end{array}$ & \\
\hline $\begin{array}{l}\text { Dependent } \\
\text { Variable } \\
\end{array}$ & $\begin{array}{l}\text { Independent } \\
\text { Variables }\end{array}$ & $\begin{array}{l}\text { Regression } \\
\text { Coefficient }\end{array}$ & t-statistic & $\begin{array}{l}\text { Regression } \\
\text { Coefficient }\end{array}$ & t-statistic \\
\hline LnFEE & $\begin{array}{l}\text { INTERCEPT } \\
\text { LnASSETS } \\
\text { SUBS } \\
\text { INVREC } \\
\text { LOSS } \\
\text { DEBT } \\
\text { OPINION } \\
\text { MNE } \\
\text { AUDITOR } \\
\text { AUDITOR*MNE }\end{array}$ & $\begin{array}{r}-0.708 \\
0.384 \\
0.010 \\
0.436 \\
-0.215 \\
0.0002 \\
0.271 \\
0.269 \\
0.032 \\
1.311 \\
\text { R-square }=.719\end{array}$ & $\begin{array}{r}-1.410 \\
10.270 * * * \\
7.018 * * * \\
2.209 * * \\
-1.171 \\
-0.333 \\
0.709 \\
0.501 \\
0.338 \\
2.259 * *\end{array}$ & $\begin{array}{r}-1.183 \\
0.419 \\
0.012 \\
0.516 \\
-0.178 \\
-0.0003 \\
0.270 \\
-0.003 \\
0.127 \\
0.021 \\
\text { R-square }=.704\end{array}$ & $\begin{array}{r}-2.310 * * \\
11.085 * * * \\
8.076 * * * \\
2.545 * * * \\
-0.948 \\
-0.630 \\
0.691 \\
-0.422 \\
1.539 \\
2.802 * * *\end{array}$ \\
\hline
\end{tabular}

Incremental $\mathrm{R}^{2}$ procedure (F test): AUDITOR*MNE variable is significant at the .05 level (Test 1), .01 level (Test 2 )

Significant at $* \alpha=.05, * * \alpha=.025, * * * \alpha=.01$ (one-tailed test)

The importance of the results described above is certainly dependent on the acceptance of the measure of multinationality. In Test 1 , the ratio of foreign to total subsidiaries was used to capture the level of multinationality of the sample firms. In order to validate this measure of multinationality, Hypothesis 1 was tested using the other measure of multinationality described in the existing literature.

The ratio of foreign sales to total sales has been used to capture the level of multinationality in a number of studies (see e.g., Sullivan 1994, Grant 1987). The problem with this measure is the fact that companies can make foreign sales without having foreign operations and vice versa. The analyses conducted using foreign sales to total sales are presented in Table 3 (Test 2). Again, the incremental $R^{2}$ procedure is used to test for the significance of the interaction. Panel A presents the reduced model with no interaction term. The model is statistically significant $(\mathrm{p}<.0001)$ and the $\mathrm{R}^{2}$ is $69.3 \%$. The AUDITOR variable is significant at the .025 level. Panel B displays the results for a model that includes the interaction of auditor and the ratio of foreign to total sales. The model $\mathrm{R}^{2}$ is $70.4 \%$. The interaction term is positive and statistically significant $(\mathrm{F}=7.99, \mathrm{p}<.01)$. The results are the same as those found using the ratio of foreign subsidiaries to total subsidiaries and support the use of subsidiary data to measure multinationality. 
Hypothesis 3 relates to the composition of the foreign subsidiaries of client firms headquartered in Malaysia. The hypothesis predicts that the magnitude of the audit fee premium charged by Big 6 firms will increase as client firms have a greater proportion of their foreign subsidiaries in developed versus developing countries. To test this hypothesis, a regression model that includes two additional variables is run on a sample of multinational clients. The added variables are DEVELOPSUB, (the ratio of the number of developed countries of operation to the total number of countries of operation) and the interaction term, DEVELOPSUB by AUDITOR. Panels A and B of Table 4 display the results for the full and reduced regression models that test for the significance of the interaction between DEVELOPSUB and auditor type (Model 2). The interaction term is positive and significant $(\mathrm{F}=12.46, \mathrm{p}<.001)$. Hypothesis 3 is supported for the Malaysian market.

TABLE 4

Malaysia - Model 2

PANEL A: reduced model (n=113; only MNE clients included)

\begin{tabular}{llrr}
\hline $\begin{array}{l}\text { Dependent } \\
\text { Variable }\end{array}$ & Independent & $\begin{array}{r}\text { Regression } \\
\text { Coefficient }\end{array}$ & t-statistic \\
\hline LnFEE & Variables & 0.668 & 0.745 \\
& INTERCEPT & 0.272 & $4.214^{* * *}$ \\
& LnASSETS & 0.013 & $6.653^{* * *}$ \\
& SUBS & 0.286 & 0.947 \\
& INVREC & -0.435 & $-1.734^{*}$ \\
& LOSS & 0.0002 & 0.285 \\
& DEBT & 0.252 & 0.497 \\
& OPINION & 1.228 & $4.274^{* * *}$ \\
& MNE (foreign subs./total subs.) & 0.273 & $2.434^{* * *}$ \\
& AUDITOR & -0.038 & -0.238 \\
R-square $=.722$ & DEVELOPSUB & & \\
\hline Significant at $* \alpha=.05, * * \alpha=.025, * * * \alpha=.01$ (one-tailed test) & & \\
\hline
\end{tabular}

PANEL B: Model 2 - full model (n=113; only MNE clients included))

\begin{tabular}{llrr}
\hline $\begin{array}{l}\text { Dependent } \\
\text { Variable }\end{array}$ & Independent & $\begin{array}{r}\text { Regression } \\
\text { Coefficient }\end{array}$ & t-statistic \\
\hline LnFEE & Variables & 1.488 & $1.683^{*}$ \\
& INTERCEPT & 0.253 & $4.113^{* * *}$ \\
& LnASSETS & 0.013 & $7.195^{* * *}$ \\
& SUBS & 0.269 & 0.936 \\
& INVREC & -0.452 & $-1.898^{*}$ \\
& LOSS & 0.0005 & 0.704 \\
& DEBT & 0.331 & 0.687 \\
& OPINION & 1.312 & $4.788^{* * *}$ \\
& MNE (foreign subs./total subs.) & -0.573 & $-2.166^{* *}$ \\
& AUDITOR & -0.878 & $-3.089^{* * *}$ \\
& DEVELOPSUB & 1.153 & $3.491^{* * *}$ \\
\hline R-square $=.752$ & AUDITOR*DEVELOPSUB & & \\
\hline Signiffca & & &
\end{tabular}

Significant at $* \alpha=.05, * * \alpha=.025, * * * \alpha=.01$ (one-tailed test)

AUDITOR*MNE variable is significant at the .001 level based on the F-test (incremental $\mathrm{R}^{2}$ procedure). 
The interpretation of the positive and significant coefficient for the interaction variable deserves further discussion. Figure 2 presents graphically the interaction between AUDITOR and DEVELOPSUB, based on the regression coefficients found in Table 4 (Panel B). ${ }^{12}$ Indeed, the Big 6 audit fee premium increases for clients that have more subsidiaries in developed countries. In fact, non-Big 6 firms actually decrease their fees for multinational clients that have a large proportion of their subsidiaries in developed countries. Non-Big 6 auditors must not have a competitive advantage in this market and, therefore, lower their price for the audits. Big-6 firms are quite familiar with reporting standards and operations in developed countries, and can deliver a differentiated (higher priced) audit to its clients. Furthermore, Big-6 auditors are potentially exposed to additional risks of reputation loss (from audit failures) introduced by the existence of developed-country subsidiaries of the client. The above results indicate that, in the Malaysian market, the location of operations of audit clients is an important consideration in determining the strength of audit firms' competitive advantages.

\section{FIGURE 2 \\ Malaysia: Result for DEVELOPSUB by AUDITOR Interaction \\ DEVELOPSUB by AUDITOR Interaction}

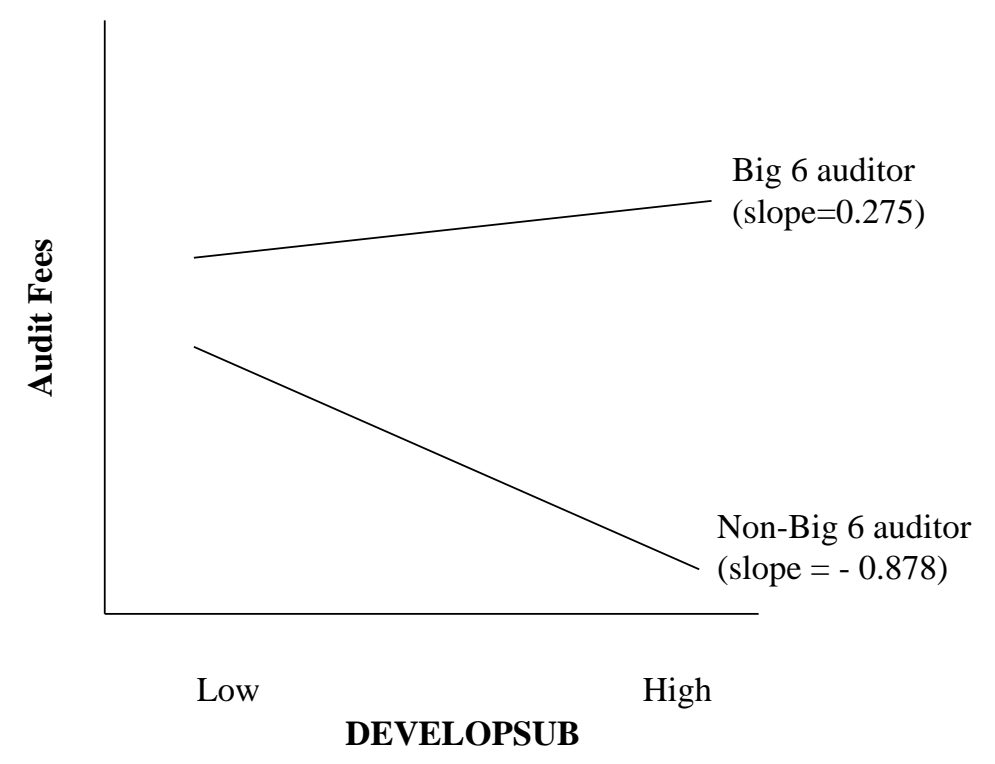

\section{Hong Kong}

The results of a regression model that tests for the existence of a Big 6 fee premium are presented in Panel A of Table 5 (Base Model for Hong Kong). The MNE variable used for this regression is the ratio of foreign to total subsidiaries (Test 1). The model explains $62.4 \%$ of the variation in audit fees. The control variables, LnASSETS, SUBS, INVREC, LOSS and MNE, are significant at the .01 level. The DEBT variable is significant at the .025 level. As predicted, all of these control variables are positively related to audit fees. The AUDITOR variable is positive and significant at the .01 level. This result confirms the existence of a Big 6 auditor fee premium in Hong Kong.

\footnotetext{
${ }^{12}$ As additional analysis for Malaysia, the sample of multinational clients was split based on Big 6 versus non-Big 6 auditors, and separate regressions were performed. The results indicate that, for the sample that included MNE clients with non-Big 6 auditors, the coefficient for the DEVELOPSUB variable was negative and significant at the .01 level (one-tailed test, t-statistic $=-2.828$ ). For the sample including MNE clients with Big 6 auditors, the coefficient for the DEVELOPSUB variable was positive and marginally significant at the .1 level (one-tailed test, t-statistic $=1.304)$.
} 
Hypothesis 2 predicts that in developed countries such as Hong Kong, the magnitude of a Big 6 auditor fee premium will increase with increased levels of multinationality of the audit client. Panels A and B of Table 5 present the test results for this hypothesis. The model in Panel B (Model 1, Test 1) includes the interaction variable, AUDITOR*MNE, where MNE is calculated as the ratio of foreign to total subsidiaries. The coefficient on the AUDITOR*MNE variable is not statistically significant (based on both the t-test and the F-test). These results do not support Hypothesis 2. It appears that Big 6 audit fee premiums do not increase as the client's ratio of foreign to total subsidiaries increases. The significant results for the MNE variable reveal that auditors, in general, charge higher fees for multinational clients. However, the Big 6 firms do not appear to charge additional premiums for larger multinationals.

To validate the above findings, analysis was conducted using an alternative measure of multinationality. Panel A of Table 5 (Test 2) presents results for a regression model using foreign sales to total sales as a measure of multinationality. This regression model is used to test for the existence of an overall Big 6 fee premium in Hong Kong (Base Model). The results support the findings documented for the foreign subsidiaries to total subsidiaries measure. To test for the interactive effects of auditor type and multinationality on audit fees, the interaction of AUDITOR*MNE is added to the regression model (see Panel B, Test 2 of Table 5). Again, the interaction term is not significant.

TABLE 5

\section{Hong Kong - Base Model and Model 1}

\begin{tabular}{|c|c|c|c|c|c|}
\hline \multicolumn{2}{|c|}{$\begin{array}{l}\text { PANEL A } \\
\text { Base Model - reduced model } \\
\mathbf{n = 2 8 0}\end{array}$} & \multicolumn{2}{|c|}{$\begin{array}{l}\text { Test } 1 \\
\text { MNE Variable = } \\
\text { Foreign Subs./Total Subs. }\end{array}$} & \multicolumn{2}{|c|}{$\begin{array}{l}\text { Test } 2 \\
\text { MNE Variable = } \\
\text { Foreign Sales/Total Sales }\end{array}$} \\
\hline $\begin{array}{l}\text { Dependent } \\
\text { Variable }\end{array}$ & $\begin{array}{l}\text { Independent } \\
\text { Variables }\end{array}$ & $\begin{array}{l}\text { Regression } \\
\text { Coefficient }\end{array}$ & t-statistic & $\begin{array}{l}\text { Regression } \\
\text { Coefficient }\end{array}$ & t-statistic \\
\hline LnFEE & $\begin{array}{l}\text { INTERCEPT } \\
\text { LnASSETS } \\
\text { SUBS } \\
\text { INVREC } \\
\text { LOSS } \\
\text { DEBT } \\
\text { OPINION } \\
\text { MNE } \\
\text { AUDITOR }\end{array}$ & $\begin{array}{r}-0.087 \\
0.422 \\
0.008 \\
0.908 \\
0.351 \\
0.0003 \\
-0.210 \\
0.685 \\
0.444 \\
\text { R-square }=.624 \\
\end{array}$ & $\begin{array}{r}-0.185 \\
14.311 * * * \\
5.642 * * * \\
4.976 * * * \\
3.821 * * * \\
2.117 * * \\
-0.723 \\
4.932 * * * \\
4.932 * * *\end{array}$ & $\begin{array}{r}0.054 \\
0.423 \\
0.008 \\
0.946 \\
0.317 \\
0.0003 \\
-0.141 \\
0.005 \\
0.465 \\
\text { R-square }=.625 \\
\end{array}$ & $\begin{array}{r}0.117 \\
14.338^{* * *} * \\
5.514 * * * \\
5.226 * * * \\
3.455 * * * \\
1.968 * \\
-0.487 \\
4.982 * * * \\
5.191 * * *\end{array}$ \\
\hline $\begin{array}{l}\text { PANEL B } \\
\text { Model } 1 \text { - } \\
\mathbf{n}=\mathbf{2 8 0}\end{array}$ & & $\begin{array}{l}\text { Test } 1 \\
\text { MNE Variable = } \\
\text { Foreign Subs./Tot: }\end{array}$ & & $\begin{array}{l}\text { Test } 2 \\
\text { MNE Variable = } \\
\text { Foreign Sales/Total }\end{array}$ & \\
\hline $\begin{array}{l}\text { Dependent } \\
\text { Variable } \\
\end{array}$ & $\begin{array}{l}\text { Independent } \\
\text { Variables }\end{array}$ & $\begin{array}{l}\text { Regression } \\
\text { Coefficient } \\
\end{array}$ & t-statistic & $\begin{array}{l}\text { Regression } \\
\text { Coefficient } \\
\end{array}$ & t-statistic \\
\hline LnFEE & $\begin{array}{l}\text { INTERCEPT } \\
\text { LnASSETS } \\
\text { SUBS } \\
\text { INVREC } \\
\text { LOSS } \\
\text { DEBT } \\
\text { OPINION } \\
\text { MNE } \\
\text { AUDITOR } \\
\text { AUDITOR*MNE }\end{array}$ & $\begin{array}{r}-0.126 \\
0.421 \\
0.008 \\
0.909 \\
0.348 \\
0.0003 \\
-0.207 \\
0.833 \\
0.509 \\
-0.172 \\
\text { R-square }=.625 \\
\end{array}$ & $\begin{array}{r}-0.262 \\
14.190 * * * \\
5.646 * * * \\
4.972 * * * \\
3.766 * * * \\
2.105 * * \\
-0.712 \\
2.225 * * \\
2.868 * * * \\
-0.426\end{array}$ & $\begin{array}{r}-0.006 \\
0.422 \\
0.008 \\
0.957 \\
0.311 \\
0.0003 \\
-0.141 \\
0.008 \\
0.539 \\
-0.003 \\
\text { R-square }=.627 \\
\end{array}$ & $\begin{array}{r}-0.013 \\
14.329 * * * \\
5.586 * * * \\
5.281 * * * \\
3.385 * * * \\
1.971 * * \\
-0.485 \\
2.933 * * * \\
4.878 * * * \\
-1.141\end{array}$ \\
\hline
\end{tabular}

Significant at $* \alpha=.05, * * \alpha=.025, * * * \alpha=.01$ (one-tailed test) 
Investigation of the composition of the foreign subsidiaries in Malaysia indicated that Big 6 firms charge significantly higher fees than non-Big 6 auditors for MNE clients with a greater proportion of their subsidiaries located in developed countries. Hypothesis 4 predicts similar results for developed countries such as Hong Kong. To test this hypothesis, a regression model was run on a sample of MNE clients. Panels A and B of Table 6 display the results of full and reduced regression models designed to test for a significant interaction between AUDITOR and DEVELOPSUB. The $\mathrm{R}^{2}$ (.643) of the full model with the interaction term is significantly higher than the $\mathrm{R}^{2}(.637)$ of the reduced model $(\mathrm{F}=4.27, \mathrm{p}<.05)$. The interaction term is significant, but negative which is opposite of the predicted direction. The relation between the location of a client's subsidiaries and audit fee premiums is not as expected.

TABLE 6

Hong Kong - Model 2

PANEL A: reduced model (n=264; only MNE clients included)

\begin{tabular}{llrr}
\hline $\begin{array}{l}\text { Dependent } \\
\text { Variable }\end{array}$ & Independent & $\begin{array}{r}\text { Regression } \\
\text { Coefficient }\end{array}$ & t-statistic \\
\hline LnFEE & Variables & -0.458 & -0.937 \\
& INTERCEPT & 0.445 & $14.569 * * *$ \\
& LnASSETS & 0.007 & $5.097 * * *$ \\
& SUBS & 0.918 & $4.975^{* * *}$ \\
& INVREC & 0.383 & $4.100^{* * *}$ \\
& LOSS & 0.0003 & $1.884 *$ \\
& DEBT & -0.200 & -0.693 \\
& OPINION & 0.677 & $4.459 * * *$ \\
& MNE (foreign subs./total subs.) & 0.474 & $5.166^{* * *}$ \\
& AUDITOR & 0.049 & 0.382 \\
R-square $=.637$ & DEVELOPSUB & & \\
\hline Significant at $* \alpha=.05, * * \alpha=.025, * * * \alpha=.01$ (one-tailed test) & & \\
\hline
\end{tabular}

PANEL B: Model 2 - full model (n=264; only MNE clients included))

\begin{tabular}{|c|c|c|c|}
\hline $\begin{array}{l}\text { Dependent } \\
\text { Variable }\end{array}$ & $\begin{array}{l}\text { Independent } \\
\text { Variables }\end{array}$ & $\begin{array}{l}\text { Regression } \\
\text { Coefficient }\end{array}$ & t-statistic \\
\hline \multirow[t]{11}{*}{ LnFEE } & INTERCEPT & -0.724 & -1.444 \\
\hline & LnASSETS & 0.436 & $14.268 * * *$ \\
\hline & SUBS & 0.008 & $5.346 * * *$ \\
\hline & INVREC & 0.889 & $4.844 * * *$ \\
\hline & LOSS & 0.365 & $3.915 * * *$ \\
\hline & DEBT & 0.0003 & $1.842 *$ \\
\hline & OPINION & -0.194 & -0.677 \\
\hline & MNE (foreign subs./total subs.) & 0.663 & $4.396 * * *$ \\
\hline & AUDITOR & 0.947 & $3.973 * * *$ \\
\hline & DEVELOPSUB & 0.734 & $2.140 * *$ \\
\hline & AUDITOR*DEVELOPSUB & -0.794 & $-2.150 * *$ \\
\hline \multicolumn{4}{|c|}{$\underline{\mathrm{R} \text {-square }=.643}$} \\
\hline \multicolumn{4}{|c|}{$\begin{array}{l}\text { AUDITOR } * \text { MNE variable is significant at the } .05 \text { level based on the F-test } \\
\text { (incremental } \mathrm{R}^{2} \text { procedure). }\end{array}$} \\
\hline
\end{tabular}


Figure 3 presents the results of the AUDITOR by DEVELOPSUB interaction term. ${ }^{13}$ In Hong Kong, Big 6 audit firms do not charge increasingly higher audit fees for MNE clients with more developed country subsidiaries. This segment of the audit market does not seem to provide Big 6 firms additional competitive advantages. However, non-Big 6 firms increase their fees for such clients. It appears that MNE clients with operations in many developed countries pose significant burdens on the non-Big 6 auditors. Non-Big 6 auditors, who are less multinational than their Big-6 counterparts, have less expertise outside of Hong Kong. They must increase their audit fees because of the increased complexity of such audits and additional risks of operating in unfamiliar territories.

\section{FIGURE 3 \\ Hong Kong: Result for DEVELOPSUB by AUDITOR Interaction}

\section{DEVELOPSUB by AUDITOR Interaction}

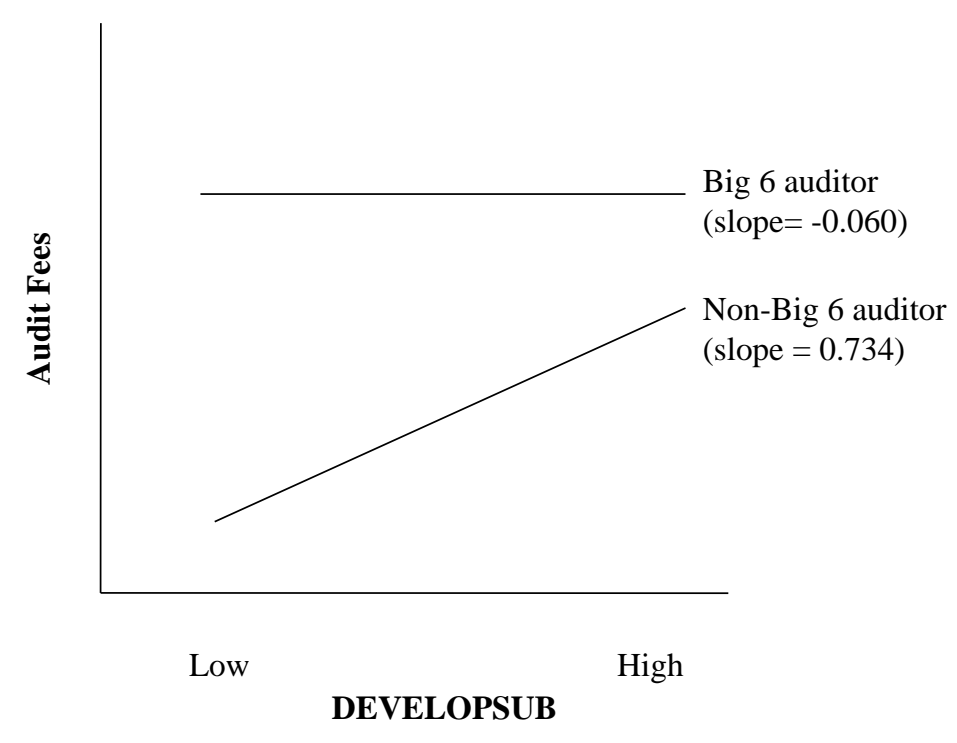

\section{United Kingdom}

The United Kingdom is another country classified as developed by the World Bank. The results of a regression model used to test for the existence of Big 6 auditor fee premiums is found in Panel A of Table 7 (Base Model). The model is significant and the coefficient on the AUDITOR variable is positive and statistically significant $(\mathrm{p}<.01)$ for both measures of multinationality (Test 1 and Test 2). These results indicate that Big 6 auditors charge fee premiums in the UK. The control variables, LnASSETS, SUBS, INVREC, LOSS, OPINION, and MNE, are all positive and statistically significant at the .01 level.

Hypothesis 2 posits that the magnitude of a Big 6 auditor fee premium will increase with increased levels of multinationality of the audit client in the UK. Panels A and B of Table 7 present the test results of reduced and full regression models designed to test Hypothesis 2. Model 1 in Panel B includes the interaction of multinationality and

\footnotetext{
${ }^{13}$ As additional analysis for Hong Kong, the sample of multinational clients was split based on Big 6 versus non-Big 6 auditors, and separate regressions were performed. The results indicate that, for the sample that included MNE clients with non-Big 6 auditors, the coefficient for the DEVELOPSUB variable was positive and significant at the .025 level (one-tailed test, t-statistic $=2.325$ ). For the sample including MNE clients with Big 6 auditors, the coefficient for the DEVELOPSUB variable was not significant (one-tailed test, $\mathrm{t}$-statistic $=-0.532$ ).
} 
auditor for both measures of multinationality (Test 1 and Test 2). Similar to the results for Hong Kong, the coefficients on the interaction terms are not statistically significant. These results fail to support Hypothesis 2 for the United Kingdom. The level of multinationality of the client increases fees for all audit firms in the UK, but multinationality does not increase fees more for Big 6 firms than for non-Big 6 firms. As mentioned previously, the United Kingdom is a highly developed G7 nation. It appears that multinational client firms do not provide Big 6 firms additional competitive advantages.

In Hong Kong, there was a significant interaction between DEVELOPSUB and AUDITOR. The next test investigates whether the same relationship exists in the UK. Hypothesis 4 states that audit fee premiums will increase for client firms with a greater proportion of subsidiaries located in developed countries relative to subsidiaries located in developing countries. Regression results are presented in Panels A and B of Table 8 (Model 2). In the UK, there is no statistically significant DEVELOPSUB*AUDITOR interaction. For clients headquartered in the UK, the location of foreign subsidiaries in other developed countries does not appear to provide any additional competitive advantages. This result differs from the result found for the other developed country, Hong Kong. Non-Big 6 auditors in Hong Kong increased their fees for clients with more subsidiaries in developed countries. This result in not confirmed in the UK market. Non-Big 6 auditors in the UK must have the necessary expertise and skills to perform such audits at a normal cost.

TABLE 7

United Kingdom - Base Model and Model 1

\begin{tabular}{|c|c|c|c|c|c|}
\hline \multicolumn{2}{|c|}{$\begin{array}{l}\text { PANEL A } \\
\text { Base Model - reduced model } \\
\mathrm{n}=917\end{array}$} & \multicolumn{2}{|c|}{$\begin{array}{l}\text { Test } 1 \\
\text { MNE Variable = } \\
\text { Foreign Subs./Total Subs. }\end{array}$} & \multicolumn{2}{|c|}{$\begin{array}{l}\text { Test } 2 \\
\text { MNE Variable = } \\
\text { Foreign Sales/Total Sales }\end{array}$} \\
\hline $\begin{array}{l}\text { Dependent } \\
\text { Variable } \\
\end{array}$ & $\begin{array}{l}\text { Independent } \\
\text { Variables }\end{array}$ & $\begin{array}{l}\text { Regression } \\
\text { Coefficient } \\
\end{array}$ & t-statistic & $\begin{array}{l}\text { Regression } \\
\text { Coefficient } \\
\end{array}$ & t-statistic \\
\hline LnFEE & $\begin{array}{l}\text { INTERCEPT } \\
\text { LnASSETS } \\
\text { SUBS } \\
\text { INVREC } \\
\text { LOSS } \\
\text { DEBT } \\
\text { OPINION } \\
\text { MNE } \\
\text { AUDITOR }\end{array}$ & $\begin{array}{r}-1.747 \\
0.548 \\
0.011 \\
0.587 \\
0.267 \\
0.00003 \\
0.179 \\
0.690 \\
0.173 \\
\text { R-square }=.761 \\
\end{array}$ & $\begin{array}{r}-9.356 * * * \\
34.255 * * * \\
7.366 * * * \\
6.026 * * * \\
5.378 * * * \\
0.606 \\
0.895 \\
8.900 * * * \\
3.025 * * *\end{array}$ & $\begin{array}{r}-1.643 \\
0.543 \\
0.010 \\
0.583 \\
0.247 \\
0.000007 \\
0.138 \\
0.009 \\
0.163 \\
\text { R-square }=.767 \\
\end{array}$ & $\begin{array}{r}-8.862 * * * \\
34.263 * * * \\
6.793 * * * \\
6.056 * * * \\
5.039 * * * \\
0.175 \\
0.696 \\
10.126 * * * \\
2.874 * * *\end{array}$ \\
\hline $\begin{array}{l}\text { PANEL B } \\
\text { Model } 1 \text { - f } \\
\text { n=917 }\end{array}$ & & $\begin{array}{l}\text { Test } 1 \\
\text { MNE Variable = } \\
\text { Foreign Subs./Tota }\end{array}$ & & $\begin{array}{l}\text { Test } 2 \\
\text { MNE Variable = } \\
\text { Foreign Sales/Tot: }\end{array}$ & \\
\hline $\begin{array}{l}\text { Dependent } \\
\text { Variable }\end{array}$ & $\begin{array}{l}\text { Independent } \\
\text { Variables } \\
\end{array}$ & $\begin{array}{l}\text { Regression } \\
\text { Coefficient }\end{array}$ & t-statistic & $\begin{array}{l}\text { Regression } \\
\text { Coefficient }\end{array}$ & t-statistic \\
\hline LnFEE & $\begin{array}{l}\text { INTERCEPT } \\
\text { LnASSETS } \\
\text { SUBS } \\
\text { INVREC } \\
\text { LOSS } \\
\text { DEBT } \\
\text { OPINION } \\
\text { MNE } \\
\text { AUDITOR } \\
\text { AUDITOR*MNE }\end{array}$ & $\begin{array}{r}-1.740 \\
0.548 \\
0.011 \\
0.588 \\
0.267 \\
0.00003 \\
0.180 \\
0.651 \\
0.165 \\
0.045 \\
\text { R-square }=.761\end{array}$ & $\begin{array}{r}-9.199 * * * \\
34.237 * * * \\
7.330 * * * \\
6.026 * * * \\
5.378 * * * \\
0.604 \\
0.898 \\
3.283 * * * \\
2.363 * * * \\
0.213\end{array}$ & $\begin{array}{r}-1.629 \\
0.543 \\
0.010 \\
0.585 \\
0.247 \\
0.000007 \\
0.141 \\
0.007 \\
0.145 \\
0.002 \\
\text { R-square }=.767\end{array}$ & $\begin{array}{r}-8.708 * * * \\
34.249 * * * \\
6.739 * * * \\
6.075 * * * \\
5.020 * * \\
0.167 \\
0.711 \\
2.706 * * * \\
2.273 * * \\
0.592\end{array}$ \\
\hline
\end{tabular}

Significant at $* \alpha=.05, * * \alpha=.025, * * * \alpha=.01$ (one-tailed test) 


\section{DISCUSSION AND CONCLUSIONS}

Location-specific advantages and audit firm characteristics moderate the effect of resources and skills on the differentiation/cost competitive positional advantages. For example, not all countries offer location advantages that would allow Big 6 firms to charge premiums. This study argues that developing countries have certain location conditions that counterbalance the benefits of the competitive advantages owned by Big 6 accounting firms. Multinational clients, however, represent a separate market for audit services where Big 6 firms can realize their competitive advantages.

This research examined the effect of brand equity, as a source of competitive advantage, on Big 6 firm pricing in the multinational client segment of the audit market. Three markets for audit services were analyzed, including markets in Malaysia, Hong Kong, and the United Kingdom. A dual market (domestic and multinational) for audit services appears to exist in Malaysia. The results indicate that audit fee premiums increase as the level of multinationality of the client increases. Big 6 auditors are able to take greater advantage of their reputation and brand name advantages in the multinational client segment.

The location of a multinational client's operations is also an important factor in determining the firm's competitive position. In Malaysia, the magnitude of the Big 6 audit fee premium increases for clients with subsidiaries in developed countries. As compared to non-Big 6 firms, Big 6 auditors have certain resources and skills that enable them to provide more desired audit services for multinational clients with developed country operations. The study found different results for the developed economies. It appears that, in Hong Kong and the United Kingdom, the location of client subsidiaries in developed countries does not provide additional competitive advantages for Big 6 firms. One explanation for this result is that client companies in Hong Kong (and the UK) are headquartered in a developed country where the Big 6 are not as differentiated from their non-Big 6 counterparts. In Malaysia, Big 6 firms are able to provide significant additional expertise (over domestic firms) in the audits of their developed MNE clients.

It is important to examine the issue of multinationality as a determinant of audit fees and fee premiums because of the growing interdependence of global markets. An increasing number of accounting firms are expanding the scope of their operations to include international markets. Firms are not only exploring the markets of developed countries, but they are also venturing into developing countries in Latin and South America, Asia, Africa, and Central and Eastern Europe. These economies are opening their doors to foreign direct investment, and the markets for audit services are expanding. Researchers must investigate how the international markets value audit services because the demand for audit services relates directly to the quality of financial disclosures in these markets.

Additionally, the presence of multinational enterprises may actually foster economic growth in developing regions. While cultural, political and legal factors are difficult to change in order to promote economic development, it is possible to influence the creation and composition of multinational enterprises. Such actions could benefit not only the MNEs and the developing nations, but also the global economy.

The theories discussed in this study involve generalizations concerning audit markets in developed and developing countries. Additional examples of countries that fall into these two categories should be investigated to support the general theory of auditor competitive advantages in developed and developing regions. A valuable extension of the study would involve examining audit pricing for countries that fall into the four different income categories provided by the World Bank. Samples could be gathered from low income countries, lower middle income countries, upper middle income countries, and high income countries. Such an analysis could provide valuable information about competitive advantages and audit economics issues for countries at four different levels of economic development. Data, however, is not readily available for the less developed countries, and alternative sources would have to be investigated. Perhaps a case-study research design would be more appropriate for such regions. 
TABLE 8

United Kingdom - Model 2

PANEL A: reduced model (n=530; only MNE clients included)

\begin{tabular}{llrr}
\hline $\begin{array}{l}\text { Dependent } \\
\text { Variable }\end{array}$ & Independent & Regression & t-statistic \\
LnFEE & Variables & -1.923 & $-6.863 * * *$ \\
& INTERCEPT & 0.571 & $28.278 * * *$ \\
& LnASSETS & 0.011 & $6.435 * * *$ \\
& SUBS & 0.582 & $4.283 * * *$ \\
& INVREC & 0.237 & $3.833 * * *$ \\
& LOSS & 0.00002 & 0.366 \\
& DEBT & -0.063 & -0.279 \\
& OPINION & 0.459 & $4.196 * * *$ \\
& MNE (foreign subs./total subs.) & 0.183 & $2.267 * *$ \\
& AUDITOR & 0.070 & 0.586 \\
R-square $=.778$ & DEVELOPSUB & & \\
\hline Significant at $* \alpha=.05, * * \alpha=.025, * * * \alpha=.01$ (one-tailed test) & \\
\hline
\end{tabular}

PANEL B: Model 2 - full model (n=530; only MNE clients included))

\begin{tabular}{llrr}
\hline $\begin{array}{l}\text { Dependent } \\
\text { Variable }\end{array}$ & Independent & Regression & t-statistic \\
VnFEE & Variables & -1.833 & $-5.156^{* * *}$ \\
& INTERCEPT & 0.571 & $28.232^{* * *}$ \\
& LnASSETS & 0.011 & $6.427 * * *$ \\
& SUBS & 0.586 & $4.299 * * *$ \\
& INVREC & 0.236 & $3.804 * * *$ \\
& LOSS & 0.00002 & 0.361 \\
& DEBT & -0.063 & -0.278 \\
& OPINION & 0.460 & $4.196 * * *$ \\
& MNE (foreign subs./total subs.) & 0.068 & 0.234 \\
& AUDITOR & -0.042 & -0.141 \\
& DEVELOPSUB & 0.131 & 0.412 \\
R-square $=.778$ & AUDITOR*DEVELOPSUB & & \\
\hline Significant at $* \alpha=.05, * * \alpha=.025, * * * \alpha=.01$ (one-tailed test) & & \\
\hline
\end{tabular}

An additional investigation of the Hong Kong market should be conducted after its transition to the Chinese rule. The study should include data gathered four or five years after the transition year in order to allow time for the adjustment. Also, the results for the UK should be compared to a new study done for the US. The US also has a highly developed auditing profession and sophisticated capital markets. The role that multinationality plays in the US audit market has not been documented. A dual market for audit services was not found in the UK. A study of the US audit market should be conducted to determine whether such a dual market exists in the US. 


\section{REFERENCES}

1. $\quad$ Benvignati, A. 1987. Domestic profit advantages of multinational firms. Journal of Business 60 (July): 449461.

2. Casson, M. 1982. Transaction costs and the theory of the multinational enterprise. In Alan Rugman, ed. New Theories of the MNE. London: Croom Helm, Ltd.

3. Caves, R. 1996. Multinational Enterprise and Economic Analysis. Cambridge: Cambridge University Press.

4. Chung, D., and W. Lindsay. 1988. The pricing of audit services: The Canadian perspective. Contemporary Accounting Research 5 (Fall): 19-46.

5. Daniels, J., and J. Bracker. Profit performance: Do foreign operations make a difference? Management International Review 29 (First Quarter): 46-56.

6. Ernst and Young. 1990. Doing Business in Hong Kong. New York: Ernst and Young International, Ltd.

7. Firth, M. 1985. An analysis of audit fees and their determinants in New Zealand. Auditing: A Journal of Practice and Theory 4 (Spring): 23-37.

8. Francis, J. 1984. The effect of audit firm size on audit prices. Journal of Accounting and Economics 6 (August): 133-151.

9. $\quad$ and D. Simon. 1987. A test of audit pricing in the small-client segment of the US audit market. Accounting Review 62 (January): 145-157.

10. _ _ and D. Stokes. 1986. Audit prices, product differentiation and scale economies: Further evidence from the Australian market. Journal of Accounting Research 24 (Autumn): 383-393.

11. Geringer, J., P. Beamish, and R. daCosta. 1989. Diversification strategy and internationalization: Implications for MNE performance. Strategic Management Journal 10 (March/April): 109-119.

12. Grant, R. 1987. Multinationality and performance among British manufacturing companies. Journal of International Business Studies 18 (Third Quarter): 79-89.

13. Haskins, M., and D. Williams. 1988. The association between client factors and audit fees: A comparison by country and by firm. Accounting and Business Research 18 (Spring): 183-190.

14. Hermanson, H., D. Hermanson, and J. Carcello. 1996. An analysis of multinational "audit failures." The International Journal of Accounting 31(3): 281-291.

15. Palmrose, Z. 1986. Audit fees and auditor size: Further evidence. Journal of Accounting Research 24 (Spring): 97-110.

16. Rose, A. 1999. Audit pricing and the role of multinational factors: A study of the Hong Kong and Malaysian markets. Advances in International Accounting 12: 129-155.

17. Shapiro, D. 1980. Foreign and Domestic Firms in Canada. Toronto: Butterworths.

18. Simon, D. 1985. The audit services market: Additional empirical evidence. Auditing: A Journal of Practice and Theory 5 (Fall): 71-78.

19. _ S. Teo, and G. Trompeter. 1992. A comparative study of the market for audit services in Hong Kong, Malaysia and Singapore. International Journal of Accounting 27(3): 234-240.

20. Simunic, D. 1980. The pricing of audit services: Theory and evidence. Journal of Accounting Research 18 (Spring): 161-190.

21. Sullivan, D. 1994. Measuring the degree of internationalization of a firm. Journal of International Business Studies 25 (Second Quarter): 325-342.

22. Sundaram, A., and J. Black. 1992. The environment and internal organization of multinational enterprises. Academy of Management Review 17 (October): 729-757.

23. World Bank. 1995. World Tables. Baltimore, MD: Johns Hopkins University Press.

24. _ 1996. Social Indicators of Development 1996. Baltimore, MD: Johns Hopkins University Press. 


\section{NOTES}

